\title{
Taphonomic aspects of vertebrate fossils from Bauru Group, Upper Cretaceous, Brazil
}

\author{
Aspectos tafonônomicos de vertebrados fósseis da parte oriental do Grupo Bauru, Cretáceo \\ Superior, Brasil
}

\author{
KARINE LOHMANN AZEVEDO *, CRISTINA SILVEIRA VEGA **, LUIZ ALBERTO FERNANDES** \\ *Universidade Federal do Paraná - Programa de Pós-Graduação em Geologia, Curitiba - PR; email: karine.lohmann@gmail.com \\ **Universidade Federal do Paraná - Departamento de Geologia, Curitiba - PR
}

\begin{abstract}
Resumo
A Bacia Bauru abrange aproximadamente 370.000 km2, ocupando parte dos estados de São Paulo, Paraná, Mato Grosso, Mato Grosso do Sul, Minas Gerais, Goiás e ainda o nordeste do Paraguai. O preenchimento da bacia ocorreu em clima semi-árido a árido, durante o Cretáceo Superior. A Bacia está dividida em dois Grupos: Bauru e Caiuá, sendo que o primeiro possui maior quantidade de registros e é o foco deste estudo. Foram realizados trabalhos de campo na região de Marília e Monte Alto (SP) e Uberaba (MG), nos quais foram visitados afloramentos para a coleta de dados estratigráficos e de materiais fósseis, além da visita às coleções dos Museus de Paleontologia de Marília e de Monte Alto (SP), Museu dos Dinossauros de Uberaba (MG) e coleção de Paleontologia da Universidade de São Paulo (USP Ribeirão Preto). Nas formações Vale do Rio Peixe, Uberaba, Marília, São José do Rio Preto e Presidente Prudente foram identificadas quatro classes bioestratinômicas relacionadas à articulação/desarticulação. Classe । representa espécimes articulados praticamente completos, correspondendo principalmente aos crocodilos e tartarugas. A Classe II compreende espécimes parcialmente articulados como crânios com mandíbulas ou sequências de vértebras. Classes I e II são registradas nas Formações Vale do Rio do Peixe, Marília ( Membro Serra da Galga) e Presidente Prudente. A Classe III é repres entada por ossos isolados e a Classe IV por ossos fragmentados. Estas duas classes ocorrem em todas as formações estudadas. Para análises diagenéticas foram feitas 19 seções delgadas que indicam que em geral, as estruturas ósseas estão bem preservadas, há preenchimento por calcita espática e manutenção da matéria fosfática original. A Formação Marília, Membro Echaporã, é a que mais se diferencia das demais unidades da bacia pelo fato de ser mais carbonática. O estudo de lâminas petrográficas, considerando a estrutura óssea e o sedimento associado, pode auxiliar na contextualização paleoambiental.
\end{abstract}

Palavras-chave: Bacia Bauru; tafonomia; vertebrados

\begin{abstract}
The Bauru Basin covers an area of about 370.000 km2, occurring in São Paulo, Paraná, Mato Grosso, Mato Grosso do Sul, Minas Gerais and Goiás states in Brazil, and also in the northeast of Paraguay. These upper Cretaceous sequence correspond to a semi-arid to arid climate and is divided in two groups, Bauru and Caiuá. The first one has the major record of fossils, being the focus of the taphonomic study. Field trips to Marília and Monte Alto municipalities (São Paulo State) and also to Uberaba city (Minas Gerais State) were made to check the depositional context and collect fossiliferous material. Vertebrate collections were visited, as the Museu de Paleontologia from Marília and Monte Alto (SP), Museu de Paleontologia da Universidade de São Paulo, as well as Museu dos Dinossauros, Centro de Pesquisas Paleontológicas Llewellyn Ivor Price from Peirópolis (MG). Four biostratinomic classes related to articulated/disarticulated fossils were identified in Vale do Rio Peixe, Uberaba, Marília, São José do Rio Preto and Presidente Prudente formations. Class I represents articulated and almost complete specimens, corresponding mainly to turtles and crocodiles. Class II comprises partially articulated specimens of skull and jaw fossils, or sequences of vertebrae. Classes I and II were recorded in Vale do Rio do Peixe, Marília (Serra da Galga Member) and Presidente Prudente formations. Class III is represented by isolated bones, and Class IV by fragmented bones. These two last classes appear in all units of the basin. For diagenetic analysis, 19 thin sections were made showing that, in general, the bone structure is well preserved, with spatic calcite filling the bone and the presence of the original phosphatic material. Marilia Formation, on Echaporã Member, is the most different unit of the basin, being more carbonatic. The study of thin sections, considering the osseous structure and the biostratinomic analysis, match with the paleoenvironmental contextualization.
\end{abstract}

Key-words: Bauru Group; taphonomy; vertebrates 


\section{Introduction}

The Bauru Basin covers an area of about $370.000 \mathrm{~km} 2$, occurring on São Paulo, Paraná, Mato Grosso, Mato Grosso do Sul, Minas Gerais and Goiás states (Brazil), and the northeast of Paraguay. The Upper Cretaceous sequence preserved on the Bauru Basin corresponds to a semi-arid to arid climate deposition.

The basin has accumulated a sandy sedimentary sequence over basalts of Serra Geral Formation (regional basement). The basin is represented by two groups, Caiuá and Bauru. The first one is constituted by Rio Paraná, Goio Erê and Santo Anastácio formations; and the second group is constituted by Vale do Rio do Peixe, Araçatuba, Uberaba, São José do Rio Preto, Presidente Prudente and Marília formations (Fernandes \& Coimbra, 2000). On this work, the
Bauru Group was considered, by its importance on the occurrence of many vertebrate fossils (Fig.1).

Considering the fossil record of the group, crocodiles and dinosaurs are most abundant, but there are also abundant records of turtles and fishes (e.g. Candeiro et al., 2004; Bertini et al., 2006; Laurini, 2007). Anura, Squamata, Aves and Mammalia are relatively rare (e.g. Baez \& Peri, 1989; Bertini et al., 1993; Alvarenga \& Nava, 2005; Candeiro et al., 2009). Ichnofossils, eggs, gastroliths and coprolites are also known from the group (e.g. Grellet-Tinner \& Zaher, 2007; Fernandes et al., 2008) Since the Bauru Group is an important paleontological site (Azevedo, 2009; Candeiro et al., 2008; Candeiro et al., 2006), this work presents a taphonomic approach to vertebrate fossils found in the group.

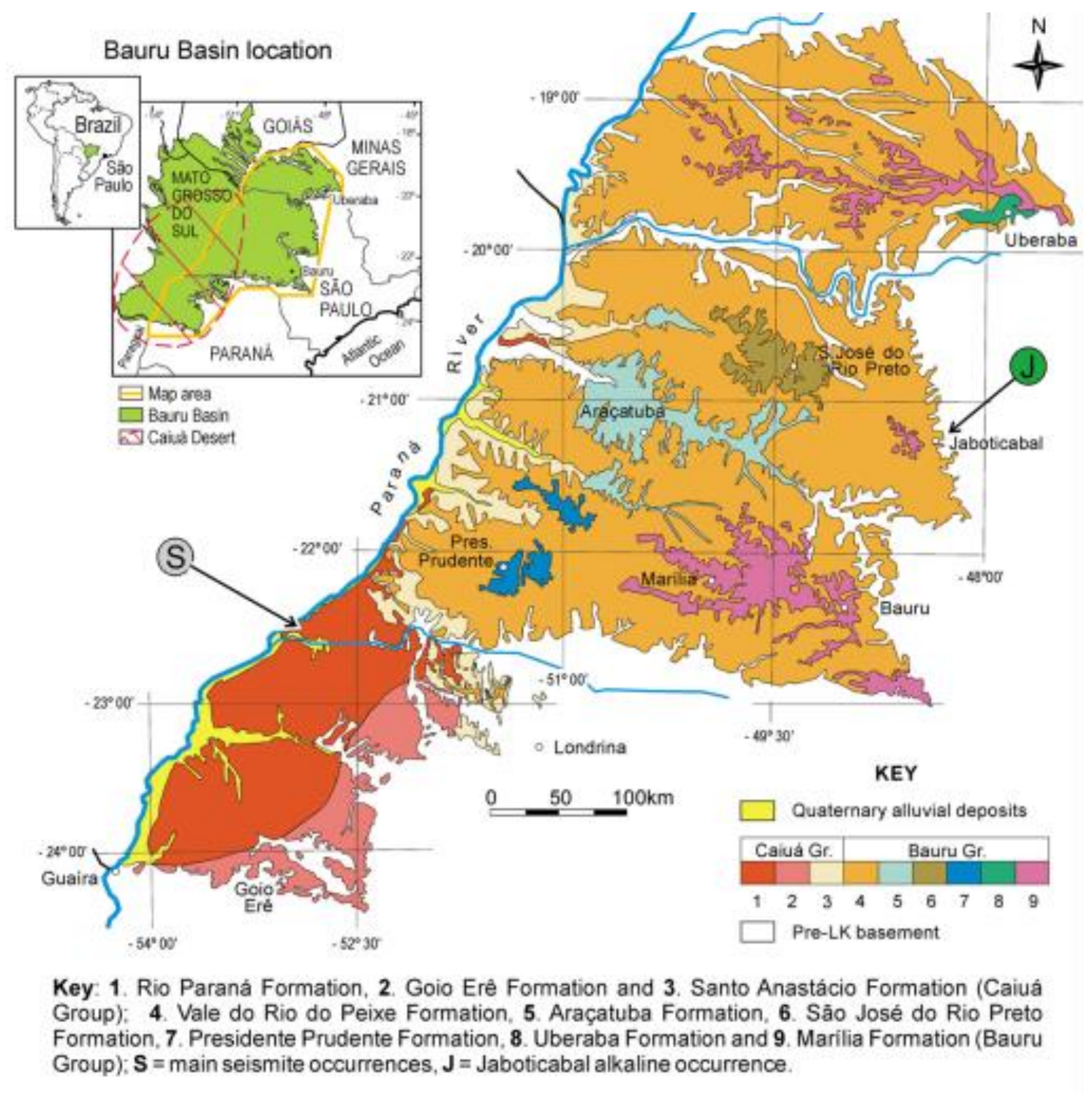

Figure 1 - Lithostratigraphic map of the Bauru Basin eastern part (after Fernandes, 2004). 


\section{Materials and methods}

The outcrops studied was from Marília Formation, Echaporã Member (22 $12^{\prime} 23,3^{\prime \prime}$ S 50 $04^{\prime} 04,4^{\prime \prime}$ W) and from Vale do Rio do Peixe Formation (22 $20^{\prime} 21^{\prime \prime} \mathrm{S}$; $49^{\circ} 56^{\prime} 39^{\prime \prime}$ W), both in Marília city (São Paulo). In Monte Alto (SP), one fossiliferous outcrop that corresponds to Vale do Rio do Peixe Formation was visited.

On Minas Gerais state, three fossiliferous outcrops were visited, all from Marília Formation. The first one corresponds to Serra da Galga Member and is known as Point 1 of Price $\left(19^{\circ} 43^{\prime} 27^{\prime \prime} \mathrm{S}, 47^{\circ} 44^{\prime} 47^{\prime \prime} \mathrm{W}\right)$; the second outcrop corresponds to the same member and is located on

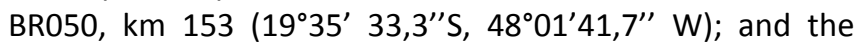
third is related to Ponte Alta Member at BR 262, km 780

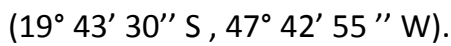

Lithological profiles were made on the outcrops and were later related with the fossils that were found. All the fossils are catalogued at Laboratório de Paleontologia do Setor de Ciências da Terra, from Universidade Federal do Paraná. In the laboratory, the samples were checked in details for possible taxonomic and taphonomic classifications.

The cientific collections visited are Museu de Paleontologia de Marília, where it was possible to observe taphonomic aspects of fossils from Marília, Vale do Rio do Peixe and Presidente Prudente formations; the Museu dos Dinossauros, in Peirópolis (Minas Gerais), were it was possible to observe fossils from Uberaba and Marília formations; and the Museu de Paleontologia de Marilia, were it was observed fossils from Vale do Rio do Peixe, Presidente Prudente and Marília formations. Nearly 240 samples of vertebrate fossils were analyzed in the museums, according to table 1.

Table 1 - Approximate amount of vertebrate fossils analyzed of Bauru Group.

\begin{tabular}{|c|c|}
\hline Formation/Member & $\begin{array}{c}\text { Approximate amount of } \\
\text { vertebrate fossils analyzed }\end{array}$ \\
\hline Vale do rio do Peixe & 50 \\
\hline Marília/Echaporã & 40 \\
\hline Marília/Serra da Galga & 100 \\
\hline Marília/Ponte Alta & 15 \\
\hline Uberaba & 5 \\
\hline Presidente Prudente & 30 \\
\hline Total & 240 \\
\hline
\end{tabular}

In order to get a better analysis of the bone's preservation, thin sections were made from the material that was found in the field and from some samples given by the museums, and also from materials already deposited on the Laboratório de Estudos Sedimentológicos from UFPR (LabESed). Four petrografic laminas from Vale do Rio do Peixe Formation were analyzed, three from Uberaba Formation, ten from Marília Formation (five of those being from Serra da Galga Member and five from Ponte Alta Member) and two from Presidente Prudente Formation.
The laminae were analyzed at a petrography microscope under polarized and regular light from LabESed, in which digital photomicrographs of the osteologic structures and most relevant minerals were seen. The bone's samples were registered at Laboratório de Paleontologia from UFPR, as UFPR.... PV A and the thin sections as UFPR .....PV B. "UFPR" corresponds to the Universidade Federal do Paraná, and "PV" is attributed to "Paleontologia de Vertebrados".

\section{Results}

\subsection{Biostratinomy}

Considering biostratinomic data, in the materials collected during the field trips and observed on vertebrate collections, it was possible to identify four biostratinomic classes related to articulated/disarticulated fossils. Class I represents articulated and almost complete specimens; Class II comprises partially articulated specimens like skull and jaw, or sequences of vertebrae; Class III is represented by isolated bones; and Class IV by fragmented bones ( Fig. 2).

This classification is similar to that presented by Holz \& Barberena (1994) for the Triassic paleoherpetofauna from South Brazil. Although, at the present work, the specimens were divided into " $A$ " and " $B$ ", with " $A$ " representing the fossils with dimensions smaller than $25 \mathrm{~cm}$, and " $B$ " that fossils bigger than " $A$ " or with $25 \mathrm{~cm}$. This artificial selection was used to separate bigger elements, such as femur of Titanosauria, from tiny elements, like post-cranial materials of Chelonia (Table 2).

Specimens of all biostratinomic classes were found on Vale do Rio do Peixe Formation and Serra da Galga Member (Marília Formation). Fossils from Ponte Alta and Echaporã members (Marília Formation) and São José do Rio Preto Formation are represented only by Classes III and IV (Table 2).

Ichnofossils, eggs and coprolites were not considered on this classification because they present a distinct taphonomic history from skeleton of vertebrates. However, they occur at Vale do Rio do Peixe, Uberaba and Marília formations.

The Biostratinomic Class I, represented by articulated skeletons, may be related to the ethologic behavior, quick buried or still to the carcass floating. As examples of this class are Uberabasuchus terrificus (Carvalho et al. 2004) and Baurubatracus pricei (Baez \& Peri, 1989).

The Biostratinomic Class II is represented by partially complete and articulated skeletons. Belong to this class the articulated skulls and jaws that are fairly common at Bauru Group, mainly among Crocodilomorpha. It is known that in the disarticulation sequence, usually, the articulation of the skull to the vertebrae (atlas-axis) is one of the first to disarticulate, that is, the organisms that present those elements had been buried in a time that allowed the loss of post-cranial elements. 

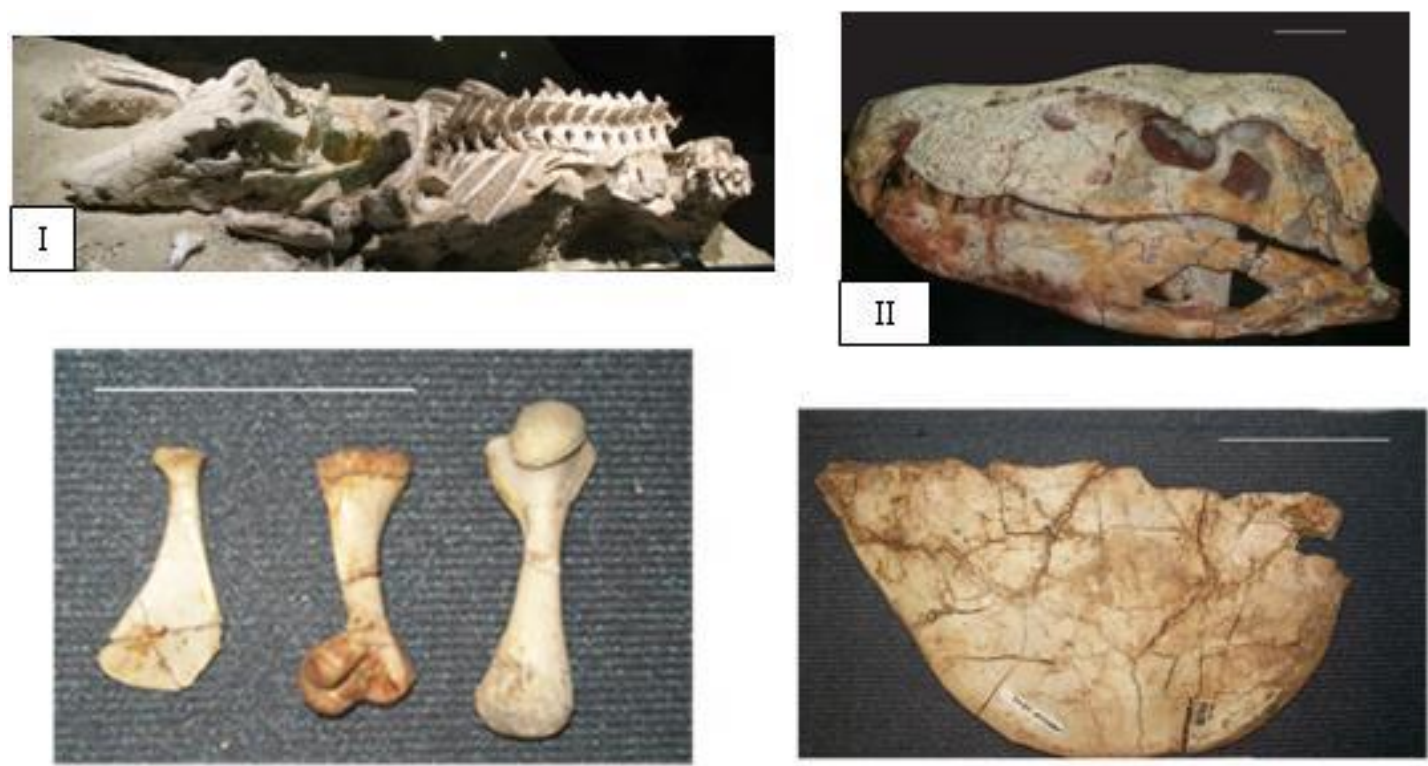

Figure 2 - Samples of biostratinomic classes. Class I. Articulated and almost complete specimens; Class II. Partially articulated specimens like; Class III. Isolated bones; Class IV. Fragmented bones. Scales bars: $5 \mathrm{~cm}$.

Table 2 - Bauru Group formations and biostratinomic classes. A. $<25 \mathrm{~cm} \mathrm{B.} \geq 25 \mathrm{~cm}$.

\begin{tabular}{|c|c|c|c|c|c|c|c|c|}
\hline \multirow[t]{2}{*}{ Formation/Classes } & \multicolumn{2}{|c|}{ Class I } & \multicolumn{2}{|c|}{ Class II } & \multicolumn{2}{|c|}{ Class III } & \multicolumn{2}{|c|}{ Class IV } \\
\hline & A & $\mathrm{B}$ & A & $\mathrm{B}$ & A & $\mathrm{B}$ & A & $B$ \\
\hline Vale do Rio do Peixe & $\mathrm{x}$ & $\mathrm{x}$ & $\mathrm{x}$ & $\mathrm{x}$ & $\mathrm{x}$ & $\mathrm{x}$ & $x$ & $\mathrm{x}$ \\
\hline Uberaba & & & & & & & $x$ & \\
\hline Marília/ Serra da Galga Member & $\mathrm{x}$ & $\mathrm{x}$ & $\mathrm{x}$ & $\mathrm{x}$ & $\mathrm{x}$ & $x$ & $\mathrm{x}$ & $\mathrm{x}$ \\
\hline Marília / Ponte Alta Member & & & & & & $x$ & $x$ & $x$ \\
\hline Marília/ Echaporã Member & & & $x$ & $x$ & $x$ & $x$ & $x$ & $x$ \\
\hline São José do Rio Preto & & & & & $\mathrm{x}$ & $\mathrm{x}$ & $\mathrm{x}$ & $\mathrm{x}$ \\
\hline Presidente Prudente & & & & $\mathrm{x}$ & $x$ & $\mathrm{x}$ & $x$ & $x$ \\
\hline
\end{tabular}

According to Holz and Barberena (1994), the fact of finding articulated skulls and jaws without appendicular skeleton may be related, in some cases, to the presence of scavengers, since they present a lower nutritional level. At the same way, at Bauru Group, there are few records of predatory spots (Kellner et al., 2006).

Articulated vertebrae, also inserted in Class II, are frequently seen at the unit (Squamata, Crocodilomorpha, Dinosauria and Chelonia). Articulated appendicular skeleton are rarely observed at Bauru Group and in some cases may be explained according to Holz and Barberena (1994) by mummification on arid environments.

So, on this work, Class II is represented by animals that, after death, had partial disarticulation, in some cases with the presence of biotic elements, such as trampling and scavengers.

The Biostratinomic Class III is represented by isolated bones. That is represented mainly by vertebrae and long bones (mainly from Dinosauria). Vertebrae are structures with porosity, that means they have high buoyancy with great dispersion in fluvial environments.

Otherwise, the Biostratinomic Class IV is the most abundant, represented by fragmented bones. Those elements were exposed to the weather for to long time before being buried. Bones may also be broken during transportation by high flows, trampling or scavengers. As mentioned above, at Bauru Group, there are few registers of teeth marks on bones, like on the description of Maxakalisaurus topai (Kellner et al., 2006). However the storms and flows must be of very high energy to break bones of recently dead animals, because they appear to be flexible. Bown \& Kraus (1981) studied a fossiliferous area in Wyoming (Estados Unidos) and found great part of the broken material as a result of high exposure, scavengers and rework at an environmental context of rainy plain. Behresmeyer (1978) also said that a bone of a recently dead animal suffers initially abrasion and rounding and after breaks. At Bauru Group mainly long broken bones were observed and also both kinds of fractures mentioned by Holz \& Simões (2002), as fractures in bones of recently dead organisms and in pre-fossilized bones.

Analyzing the biostratinomic classes presented on this work and the Voohries groups, different bone elements are registered on different levels of hydraulic transportation, and those easily removed elements occur in every formation, while skulls and jaws only occur at Vale do Rio do Peixe, Marília (Serra da Galga Member) and Presidente Prudente formations.

\subsection{Diagenesis}

According to the microscopic analysis, the bone material is well preserved, with phosphate composition in most of the cases. 
Analyzing the work from Holz and Schultz (1998), that made a taphonomic analysis on Triassic vertebrates from Paraná Basin, the 19 materials analyzed on Bauru Group on this work are better preserved. In most of the cases, it is possible to recognize concentric lamination, lamelae and osteocytes lacunae, with some peculiarities according to the formation, as discussed below.

At Vale do Rio do Peixe Formation occurs sparry calcite, and it is possible to visualize the bone microstructures (Fig. 3.1). There are also fragments of igneous rocks, probably related to the Serra Geral Formation (stratigraphically on the base) (Fig. 3.2).

At Uberaba Formation, the cementation (oxides/hydroxides) occurs in a larger quantity and it is posterior to calcitic (Fig. 3.3). This occurs probably because it is close to the basalts at Serra Geral Formation. The presence of these oxides had already been commented by Goldberg (1995). On all thin sections of this formation, there is a mineral related to silica (Fig. 3.4). In one petrographical thin section, there is probably zoned dolomite crystals (Fig. 3.5).

At Serra da Galga Member, on Marília Formation, all thin sections were made with materials collected on the outcrop from $\mathrm{Km} \mathrm{153,} \mathrm{BR} \mathrm{050,} \mathrm{between} \mathrm{Uberaba} \mathrm{and}$ Uberlândia cities (MG). At this place, fossils are found in several stratigraphycal levels, mainly in all the exposed section, almost always disarticulated and fragmented, with the exception of the dinosaur Uberabatitan ribeiroi (Salgado \& Carvalho, 2008). On the petrographical analysis, the structure of the bones is well preserved, firstly with the entrance of immature detritic material, later the spatic carbonate and finally a percolation of oxides/hydroxide (Fe and $\mathrm{Mn}$ ). Considering that, in this outcrop, most of the records is characterized by fragments, that means transportation and exposure and, on the other hand, because of the good preservation of the structures that were observed on the lamina, it can be assumed that there must have been rework of the material, previously buried and fossilized, in aggrement with Fernandes's (1998) idea for the interpretation of the presence of rivers, with flows at certain points (Figs. 4.1 and 4.2).

Considering the diagenesis, Echaporã Member (Marília Formation) is the one that shows more differences related to the other formations, since at this unit the preservation of the phosphate composition is smaller, and was replaced by calcite (Fig. 4.3). On the bone fragments analyzed, a larger quantity of immature sedimentar material was noticed filling blanks in the bones's structure, which means that those bones are more exposed and were broken before buried, allowing the entrance of material (Fig. 4.4).

Fernandes (1998) has also emphasized that at Echaporã Member the calcite highly replaced osseous material, as a result of more availability of $\mathrm{Ca}$ and $\mathrm{CO} 3$ in the environment. Fernandes (2010) studied the calcretes genesis at this unit and concluded that they are mainly from freatic origin, an environmental context which agrees with the replacement of phosphate for carbonate. In spite of the intense carbonatic cementation at this member, the original outlines of bones were visible, making it possible to identify the bone structures.

On studied material from Presidente Prudente Formation, there is observed a good preservation of bone structures. Firstly, there was a filling of sparry calcite, which was later melted, and in its place oxide appeared with irregular and acicular aspects (Fig.4.5).

Field trips and thin sections from São José do Rio Preto Formation were not made. Fernandes (1998) claimed that such unit has predominance of Titanosauria dinosaurs and crocodiles, that usually occur on sandy levels with pelitic intraclasts. The depositional environment assumed by the author was one of extensive sandy plains, periodically crossed by fluvial flows, that remobilized the organisms and concentrated the rests in sandy bars. On petrographical analysis, Fernandes (1998) verified that osteons were also filled by sparry carbonate, as the author observed at Presidente Prudente Formation, and also observed in this work, in all formations.

\section{Discussion/conclusion}

The presence of sparry calcite in all samples could be attributed to the interior continental semi-arid to arid environment, assumed by previous studies of sedimentary evolution at the basin (Fernandes, 1998, Fernandes \& Coimbra, 2000). Rainy times interchanged with dry periods, and during this last one, water evaporated quickly, favoring carbonate's precipitation (Holz \& Schultz, 1998).

The depositional environment interferes directly on the preservation of organisms, as observed at Bauru Group, where the taphonomic and geological records are related to each other.

The Vale do Rio do Peixe Formation is mainly compounded by sand sheets with dunes and interdunes (Fernandes \& Coimbra, 2000). The Formation has several fossils at weathering level more advanced, presenting brands and fractures. This fact may be related to long time of residence, for example on sandy sheet plains.

Uberaba Formation, on which just fragments were observed, but that also has dinosaurs eggs preserved, is characterized by sand bars, being its environment considered as fluvial braided (Fernandes \& Coimbra, 2000).

On the Marilia Formation, the three units (Serra da Galga, Ponte Alta and Echaporã members) are distinct in relation to the depositional environment.

The Serra da Galga Member presents coarse to fine arenites, usually conglomeratic, and the depositional environment is interpreted as fluvial braided system (Fernandes \& Coimbra, 2000). This unit has the biggest quantity of vertebrate fossil record, even being most of it fragmented.

In relation to the Ponte Alta Member, that it is very similar to Serra da Galga Member, but more cemented. From this member, just fragments were observed, probably due to the difficulty of prospection caused by the cementation. 

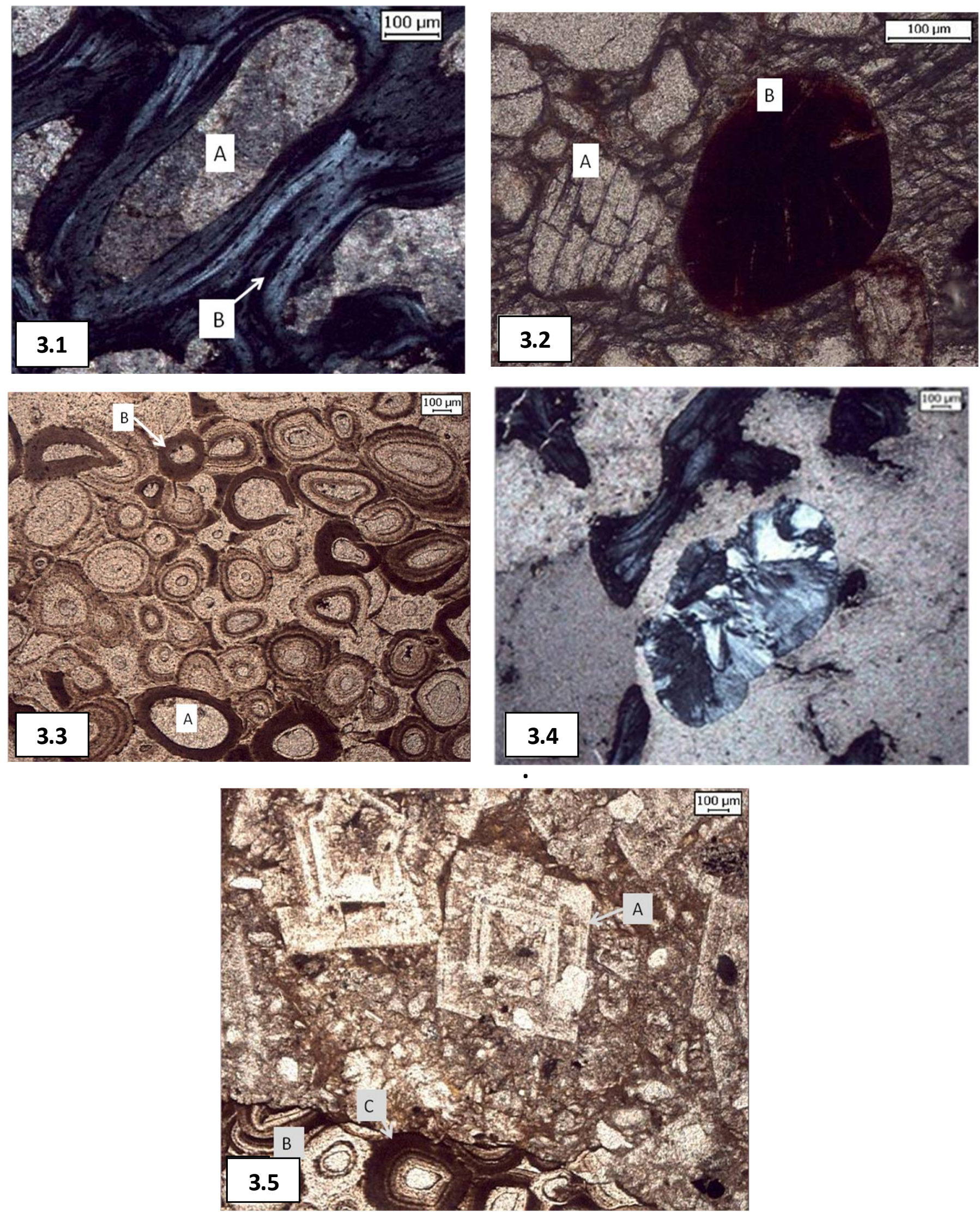

Figure 3.1 - Photomicrography of the material UFPR 0157 PV B, crossed polarizers, Vale do Rio do Peixe Formation. A. Spatic Calcite B. Osteocytes lacunae. Figure 3.2 - Photomicrography of the material UFPR 0155 PV B, Vale do Rio do Peixe Formation. A. Feldspar. B. Fragment of igneous rock. Figure 3.3 - Photomicrography of the material UFPR 0159 PV B, Uberaba Formation. Presence of osteons. A. Calcite. B. Oxide. Figure 3.4 - Photomicrography of the material UFPR 0160 PV B, crossed polarizers, Uberaba Formation. In the middle of the photo, there is the mineral related to silica. Figure 3.5 - Photomicrography of the material UFPR 0159 PV B, Uberaba Formation. A. Dolomite. B. Osteons. C. Oxide. 

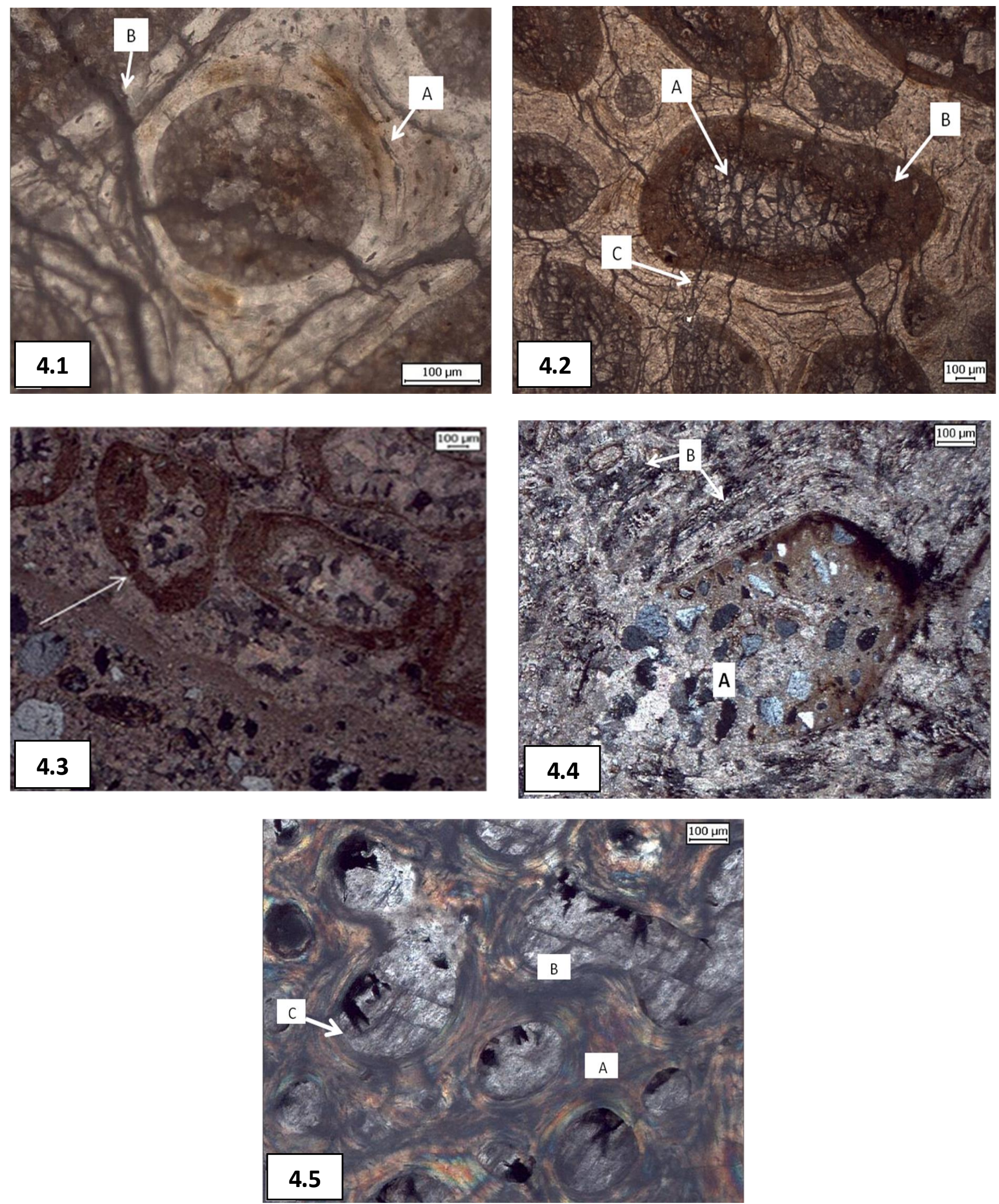

Figure 4.1 - Photomicrographs of the material UFPR 0129 PV B, Marília Formation, Serra da Galga Member. 1. A. Osteocytes lacunae. B. Microfractures. Figure 4.2 - photomicrographs of the material UFPR 0129 PV B, Marília Formation, Serra da Galga Member. A. Sparry carbonate . B. Micritic carbonate. C. Microfractures. Figure 4.3 - Photomicrography of the material UFPR 0122 PV B, crossed polarizers, Marilia Formation, Echaporã Member. Note the presence of osteons. Figure 4.4 - Photomicrography of the material UFPR 0123 PV B, crossed polarizers, Marília Formation, Echaporã Member. A. Immature sediment. B. Bone structure. Figure. 4.5 - Photomicrography of the material UFPR 0126 PV B, Presidente Prudente Formation. A. Bone structure. B.Sparry Calcite. C. Oxide with acicular aspect. 
The Echaporã Member is composed by sand sheets deposits (Fernandes \& Coimbra, 2000). Residual lakes have fragments of vertebrate fossil records, but there are also isolated bones. The preservation of the bone structure is smaller, that might be related to fewer deposition, for instance on the deflation plains and therefore long time of residence of the fossils.

The São José do Rio Preto Formation is composed by sand and residual lakes. Its depositional environment was interpreted as fluvial linked deposition (Fernandes \& Coimbra, 2000). In this case, the presence of bone fragments and other bioclasts are relatively common at the conglomeratic levels, record mainly formed by transported bones and carcasses.

The Presidente Prudente Formation, according to Fernandes and Coimbra (2000), has evidences of filled channel and crevasse splays, caracterizing a meandering fluvial system. At the facies of flood plains and crevasse splays, as Fernandes and Coimbra (2000) had already said, there might be more articulated organisms, like turtles. According to the same authors, bone fragments with remobilized clasts can be found at facies of channel fill.

Araçatuba Formation is not considered on this work, since the fossiliferous content is composed mainly by microfossils and invertebrates. The paleoenvironmental context is interpretated as ephemeral palustrine (Fernandes \& Coimbra, 2000).

Considering the taphonomic data of Bauru Group, correlation between biostratinomic and diagenetic features, as well as depositional environment, from each unit is presented on Table 3 .

The depositional context of the semi-arid climate of Bauru Basin besides determining the level of fossils preservation has also influenced on its distribution. Life has developed on humid places, like flood plains and residual lakes (Bauru Group), while in arid climates, as at Caiuá Group, there are less fossil records.

It is clear, as Fernandes (1998) had already observed, that there is lack of information about the depositional environment at Bauru Basin, which is found on a few paleontological studies, but without details.

Considering the preservation of a great quantity of fragmented and disarticulated fossils, the absence of taxonomic classification makes difficult taphonomic proposals.

The discussion about the preservation level of fossils is done according to their description, with lack of deeper and more specific taphonomic works. There are some attempts in using isotopes for paleoenvironmental discussion and also microscopic analysis of the preservation, which shows many possibilities of studies at the basin.

Table 3-Vertebrate taphonomic aspects from units of Bauru Group. A. $<25 \mathrm{~cm}$. B. $\geq 25 \mathrm{~cm}$.

\begin{tabular}{|c|c|c|c|c|}
\hline $\begin{array}{l}\text { Lithostratigraphic } \\
\text { units }\end{array}$ & Lithology & $\begin{array}{l}\text { Depositional setting/main } \\
\text { lithofacies }\end{array}$ & $\begin{array}{l}\text { Biostratinomic } \\
\text { classes }\end{array}$ & Textural and diagenetic features \\
\hline $\begin{array}{l}\text { Vale do Rio do Peixe } \\
\text { Fm. }\end{array}$ & $\begin{array}{l}\text { Fine to very fine } \\
\text { sandstones, } \\
\text { sometimes } \\
\text { interlayered with } \\
\text { mudstones }\end{array}$ & $\begin{array}{l}\text { Sand sheet plains with small } \\
\text { Aeolian dunes and } \\
\text { wadis/laterally massive } \\
\text { continuous beds, sometimes } \\
\text { with cross-bedding or muddy } \\
\text { lenses intercalations }\end{array}$ & $\begin{array}{l}\text { I (A,B); II }(A, B) ; \text { III } \\
\quad(A, B) ; \text { IV }(A, B)\end{array}$ & $\begin{array}{c}\text { Bone framework are well preserved, in immature } \\
\text { sediments (matrix), sometimes with fragments of } \\
\text { igneous rock; cavities are filled by sparry calcite and } \\
\text { ferruginous cement }\end{array}$ \\
\hline Uberaba Fm. & $\begin{array}{l}\text { Very fine } \\
\text { sandstones and silty } \\
\text { mudstones }\end{array}$ & $\begin{array}{l}\text { Braided fluvial systems/sandy } \\
\text { bars and floodplains deposits }\end{array}$ & IV $(A)$ & $\begin{array}{l}\text { Bone framework are well preserved, in immature } \\
\text { sediments (matrix); bone cavities are filled by sparry } \\
\text { calcite and a lot of ferruginous cement }\end{array}$ \\
\hline $\begin{array}{c}\text { Marília Fm. } \\
\text { Serra da Galga Mb. }\end{array}$ & $\begin{array}{l}\text { Coarse to fine } \\
\text { sandstones, often } \\
\text { conglomeratic }\end{array}$ & $\begin{array}{l}\text { Braided fluvial systems, of } \\
\text { alluvial fans distal parts, residual } \\
\text { inter-lobe lakes /sandy and } \\
\text { gravel bars deposits }\end{array}$ & $\begin{array}{l}\text { I }(A, B) ; \text { II }(A, B) ; \text { III } \\
(A, B) ; \text { IV }(A, B)\end{array}$ & $\begin{array}{l}\text { Bone framework are well preserved, in immature } \\
\text { sediments (matrix); bone cavities are filled by sparry } \\
\text { calcite and ferruginous cement }\end{array}$ \\
\hline $\begin{array}{l}\text { Marília Fm. } \\
\text { Ponte Alta Mb. }\end{array}$ & $\begin{array}{l}\text { Strongly carbonate- } \\
\text { cemented } \\
\text { sandstones }\end{array}$ & $\begin{array}{l}\text { Braided fluvial systems, of } \\
\text { alluvial fans distal parts/sandy } \\
\text { and gravel bars deposits }\end{array}$ & III (B); IV (A) & - \\
\hline $\begin{array}{l}\text { Marília Fm. } \\
\text { Echaporã Mb. }\end{array}$ & $\begin{array}{l}\text { Fine to medium } \\
\text { sandstones, with } \\
\text { minor intercalations } \\
\text { of sandy } \\
\text { mudstones, and } \\
\text { calcretes horizons }\end{array}$ & $\begin{array}{l}\text { Sand sheet plains with } \\
\text { wadis/laterally massive } \\
\text { continuous beds with muddy } \\
\text { lenses intercalated }\end{array}$ & III $(A, B) ;$ IV $(A, B)$ & $\begin{array}{l}\text { Bone framework are bad preserved, in immature } \\
\text { sediments (matrix); bone cavities are filled by sparry } \\
\text { calcite and ferruginous cement }\end{array}$ \\
\hline $\begin{array}{c}\text { São José do Rio Preto } \\
\text { Fm. }\end{array}$ & $\begin{array}{l}\text { Coarse to fine } \\
\text { sandstones, often } \\
\text { conglomeratic }\end{array}$ & $\begin{array}{l}\text { Braided fluvial systems/Sandy } \\
\text { bars, floodplains and residual } \\
\text { lake deposits }\end{array}$ & III $(A, B) ;$ IV $(A, B)$ & - \\
\hline Presidente Prudente Fm. & $\begin{array}{l}\text { Fine to very fine } \\
\text { sandstones }\end{array}$ & $\begin{array}{c}\text { Sandy meandering fluvial } \\
\text { systems/large-scale lensoid } \\
\text { sand bodies encased in fine- } \\
\text { grained deposits, cut-and-fill } \\
\text { channel }\end{array}$ & $\begin{array}{c}\text { II }(A, B) ; \text { III }(A, B) ; \text { IV } \\
(A, B)\end{array}$ & $\begin{array}{l}\text { Bone framework are well preserved, in immature } \\
\text { sediments (matrix); bone cavities are filled by sparry } \\
\text { calcite and ferruginous cement }\end{array}$ \\
\hline
\end{tabular}


Discussion on literature concerning the sedimentation of paleoenvironments and lithofacies are rare on paleontological works, avoiding studies on biostratigraphy and taphonomy. The material deposited in museums most of the time reflects this problem, since it doesn't bring details according to the origin of such materials such as stratigraphic levels, spatial density, diagenesis, or what materials were found on the same level. On this way, most of the published work and data obtained by analysis of the material from collections prevent a detailed taphonomic study. Therefore, future works that may consider biostratigraphic aspects may help to increase the taphonomic refinement of the Bauru Group.

Acknowledgments: The authors thank Museu de Paleontologia de Marília, Museu de Paleontologia de Monte Alto, Museu de Paleontologia of Universidade de São Paulo and Museu dos Dinossauros, Peirópolis, for visit on collections. To the Laboratório de Laminação of Universidade Federal do Paraná, for the thin sections. The first author also thanks CNPq (project 411717/2007-0) and CAPES for financial support.

\section{References}

ALVARENGA H, NAVA, W.R. 2005. Aves Enantiornithes do Cretáceo Superior da Formação Adamantina do Estado de São Paulo, Brasil. in: Congresso Latino Americano de Paleontologia de Vertebrados, $2,20$.

AZEVEDO K.L. 2009. Fósseis registrados na Bacia Bauru, Cretáceo Superior do Brasil: um levantamento bibliográfico. Monografia de conclusão de Curso de Ciências Biológicas. Universidade Federal do Paraná. 75 p.

BAEZ A.M., PERI, S. 1989.. Baurubatrachus pricei, nov. gen. et sp., un Anuro del Cretacico Superior de Minas Gerais, Brazil. Anais da Academia Brasileira de Ciências, Rio de Janeiro, 61, 447-458.

BEHRENSMEYER A.K. 1978. Taphonomic and ecologic information from bone weathering. Paleobiology, 4, 150-162.

BERTINI R.J., MARSHALL L.G., MIREILLE GAYET V., BRITO P. 1993. Vertebrate faunas from the Adamantina and Marilia formations (Upper, Baurú Group, Late Cretaceous, Brazil) in their stratigraphic and paleobiogeografhic context. Neues Jahrbuch für Geologie und Paläontologie, 188, 71-101.

BERTINI R.J., SANTUCCI R.M., TOLEDO C.E.V., MENEGAZZO, M.C. 2006. Taphonomy And Depositional History Of An Upper Cretaceous Turtle-Bearing Outcrop From The Adamantina Formation, Southwestern São Paulo State. Revista brasileira de paleontologia, 9 (2), 181-186.

BOWN T.M., KRAUS M.J. 1981.Vertebrate fossil-bearing paleosol units (Willwood Formation, Lower Eocene, northwest Wyoming, USA): implications for taphonomy and assemblage analysis. Paleogeography, paleoclimatology, Paleoecology, 34, 31-56.

CANDEIRO C.R.A., ABRANCHES C.T., ABRANTES E.A., ÁVILLA L.S., MARTINS V.C., MOREIRA A.L., TORRES S.R., BERGQVIST L.P. 2004.. Dinosaurs Remains from Western São Paulo State, Brazil (Bauru Basin, Adamantina Formation Upper Cretaceous). Journal of South American EarthScienceS, 1, 1-10.

CANDEIRO C.R.A., MARTINELLI A.G., AVILLA L S,. RICH T. H. 2006. Tetrapods from the Upper Cretaceous (TuronianeMaastrichtian) Bauru Group of Brazil: a reappraisal. Cretaceous Research, 27, 923-946.

CANDEIRO C.R.A., SANTOS A.R., BERGQVIST L.P., RIBEIRO LC.B., APESTEGUÍA S. 2008. The Late Cretaceous fauna and flora of the Uberaba area (Minas Gerais State, Brazil). Journal of South American Earth Sciences, 25, 203-216.

CANDEIRO C.R.A., NAVA W., MARTINELLI A.G., FORASIEPI A.M., SCANFERLA C.A., MUZZOPAPPA P. 2009. New Lizard Record (Diapsida, Lepidosauria) From the Upper Cretaceous Adamantina Formation, Brazil. Bulletin of Geosciences, 84 (1), 1-4.

CARVALHO I.S., RIBEIRO L.C.B., AVILLA L.S. 2004.Uberabasuchus terrificus sp. nov., a new crocodylomorpha from the Bauru Basin (Upper Cretaceous). Brazil. Gondwana Research, 7, 975 -1002.

FERNANDES L.A. 1998. Estratigrafia e evolução geológica da parte oriental da Bacia Bauru (Ks, Brasil).Tese de Doutorado, Instituto de Geociências, Universidade de São Paulo (USP). São Paulo. 216 p.
FERNANDES L.A. 2004. Mapa litoestratigráfico da parte oriental da Bacia Bauru (PR,SP,MG), escala 1:1.000.000. Boletim Paranaense de Geociências, 55, 53-66.

FERNANDES L.A. 2010. Calcretes e registros de paleossolos em depósitos continentais neocretáceos (Bacia Bauru, Formação Marília). Revista Brasileira de Geociências. 40 (1), 19-35.

FERNANDES L.A., COIMBRA A.M. 2000. Revisão estratigráfica da parte oriental da Bacia Bauru (Neocretáceo).Revista Brasileira de Geociências. 30 (4), 717-728.

FERNANDES L.A., SEDOR F.A., SILVA R.C., SILVA L.R., AZEVEDO A.A., SIQUEIRA A.G. 2008. Icnofósseis da Usina Porto Primavera, SP Rastros de dinossauros e de mamíferos em rochas do deserto neocretáceo Caiuá. In: Winge,M.; Schobbenhaus,C.; Souza,C.R.G.; Fernandes,A.C.S.; Berbert- Born,M.; Queiroz,E.T.; (Edit.) Sítios Geológicos e Paleontológicos do Brasil. Site: http://www.unb.br/ig/sigep/sitio013/sitio013.pdf.

GOLDBERG K. 1995. Reconstituição paleoambiental do cretáceo continental brasileiro na região do triângulo mineiro.. dissertação de mestrado, universidade do vale do rio dos sinos/unisinos, RS. $181 \mathrm{p}$.

GRELLET-TINER G., ZAHER H. 2007 Megaloolithid Eggs of the Bauru Basin and Auca Mahuevo. Papeis Avulsos de Zoologia, 47 (7), 105112.

HOLZ M., BARBERENA M.C. 1994.Taphonomy of the south Brazilian Triassic paleoherpetofauna pattern of death, transport and burial. Paleogeography,Paleoclimatology, Paleoecology, 107, 179-197.

HOLZ M., SCHULTZ, C. L.1998.Taphonomy of the south Brazilian Triassic herpetofauna: fossilization mode and implications for morphological studies. Lethaia, 31, 335- 345.

HOLZ M., SIMÕES M.G. 2002. Elementos Fundamentais de Tafonomia. Porto Alegre: Ed. Universidade/UFRGS, 231p.

KELLNER A.W.A., CAMPOS D, AZEVEDO S.A.K.,TROTTA M.N.F., HENRIQUES D.D.R., CRAIK M.M.T., SILVA H.P. 2006. On a New Titanosaur Sauropod from the Bauru Group, Late Cretaceous of Brazil. Bol. Mus. Nac., N.S., Geol. Rio de Janeiro, 74, 1-31.

LAURINI C.R. 2007. 'Microrrestos' de vertebrados da região de Ibirá, noroeste do estado de São Paulo (Grupo Bauru, Cretáceo Superior). Monografia -, Departamento de Biologia, Faculdade de Filosofia, Ciências e Letras de Ribeirão Preto, Universidade de São Paulo, $46 \mathrm{p}$.

SALGADO L., CARVALHO I.S. 2008.Uberabatitan Ribeiroi, A New Titanosaur From the Marília Formation (Bauru Group, Upper Cretaceous), Minas Gerais, Brazil. Palaeontology, 51 (4): 881-901.

Manuscrito ID 27524 Submetido em junho de 2012 Aceito em maio de 2013 